\title{
PELATIHAN PENGAJARAN MENGGUNAKAN QUIZIZZ PADA MATA PELAJARAN BAHASA INGGRIS UNTUK SISWA SMP PADA GURU-GURU SMPN 2 KEDIRI, LOMBOK BARAT NTB
}

\author{
Moh. Fauzi Bafadal'), Rima Rahmaniah'), Ilham¹) \\ 1)Program Studi Pendidikan Bahasa Inggris, FKIP, Universitas Muhammadiyah Mataram, Mataram, NTB, Indonesia \\ Corresponding author: Moh. Fauzi Bafadal \\ E-mail : fauzi.bafadal@gmail.com
}

Diterima 29 November 2021, Direvisi 22 Desember 2021, Disetujui 22 Desember 2021

\begin{abstract}
ABSTRAK
Tujuan utama pengabdian kepada masyarakat ini yaitu untuk meningkatkan kompetensi guru dalam mengelola kelas online melalui pelatihan pengajaran menggunakan Quizizz pada mata pelajaran Bahasa Inggris untuk siswa SMP pada guru-guru SMPN 2 kediri. Quizizz merupakan web tool untuk membuat permainan kuis interaktif yang digunakan dalam pembelajaran di kelas. Quizizz tidak hanya dapat dikerjakan saat pembelajaran di kelas saja, tetapi juga dapat dibuat soal untuk pekerjaan rumah, sehingga dapat dimainkan kapan saja dan dimana saja oleh siswa asalkan tidak melebihi batas waktu. Hasil observasi awal ditemukan bahwa guru-guru menggunakan WA Group dan Google Classroom. Pelatihan dilakukan dengan pemberian materi, tanya jawab, dan praktek pembuatan media Quizizz . Untuk mengetahui keberhasilan kegiatan pengabdian ini, dilakukan evaluasi dengan pengisian angket respon terhadap kepuasan menggunakan Quizizz. Hasil angket menunjukkan respon peserta pelatihan puas terhadap pelaksanaan PKM ini dan menjawab sangat mudah sebesar $100 \%$. Tingkat kepuasan peserta pelatihan dari segi materi, penyampaian materi, proses diskusi serta pelatihan individu $100 \%$. Sedangkan $50 \%$ menyatakan mengalami peningkatan terkait kemampuan menggunakan media Quizizz dan pengelolaan kelas online. Dari hasil pelatihan disarankan agar guru-guru di masa pandemi ini memahami dan menggunakan media Quizizz agar evaluasi pembelajaran terhadap siswa lebih efektif dan menyenangkan.
\end{abstract}

Kata kunci: pelatihan; guru; Quizizz .

\begin{abstract}
This community services aims to improve teacher competency in administering online classes by providing junior high school teacher at SMPN 2 Kediri with Quizizz training. Quizizz is a website that allows you to create interactive quiz games in the classroom. Quizizz can be used in class and to create homework questions so that students can play it whenever and wherever they choose as long as the time limit is not exceeded. English teachers use WA Group and Google Classroom after performing preliminary observation. The training was conducted by distributing materials, discussion, and offering hands-on practice in creating Quizizz media. An evaluation was done to determine the success of this service activity by filling out a response questionnaire to in using Quizizz . The findings of the questionnaire revealed that the training participants were satisfied with the implementation of this activity and answered very easily by $100 \%$. The level of satisfaction of the training participants in material, material delivery, discussion process, and individual training is $100 \%$. Meanwhile, $50 \%$ of the respondents said their abilities improved in using Quizizz media. It is suggested that teachers understand and use the Quizizz during this pandemic so that student evaluation of learning is more enjoyable.
\end{abstract}

Keywords: training; teacher; Quizizz .

PENDAHULUAN

Penjabaran dari UU No. 20 tahun 2003 tentang sistem pendidikan nasional, mendasarkan pada profesionalisme guru, yaitu standar kompetensi yang harus dikuasai seorang pendidik (guru). Dijelaskan, standar kompetensi yang harus dimiliki guru mencakup empat jenis kompetensi yaitu: kompetensi pedagogik, kepribadian, profesional, dan sosial. Pemenuhan kompetensi tersebut merupakan bentuk pemenuhan tanggung jawab kepada masyarakat sebagai penyedia layanan jasa pendidikan. Dengan adanya syarat kompetensi yang harus dimiliki oleh seorang guru, pelayanan jasa pendidikan yang 
diberikan kepada siswa dapat dilakukan dengan maksimal.

Keempat kompetensi tersebut bukan sebuah kompetensi yang stagnan, akan tetapi harus senantiasa dikembangkan dan latih. Hal itu dikarenakan konsep pendidikan dan model pelayanan pendidikan selalu mengalami perkembangan seiring berkembangnya masyarakat.Selain itu, perkembangan ilmu pengetahuan dan teknologi juga memberikan kesempatan dan tantangan kepada para guru untuk dapat memberikan pengalaman belajar yang lebih efektif dan efisien.Dengan demikian, guru harus selalu mengembangkan kompetensinya sebagai wujud dari tenaga professional.

Dari hasil observasi di SMPN 2 Kediri diketahui bahwa banyak guru yang belum mengoptimalkan peran media pembelajaran di dalam kegiatan pembelajaran yang dilakukan. Media pembelajaran merupakan tambahan di dalam setiap kegiatan pembelajaran karena media pembelajaran berfungsi untuk mempermudah daya serap siswa terhadap materi yang disampaikan. Meskipun demikian, media pembelajaran memiliki peran yang sangat penting karena media pembelajaran dapat memberikan daya nalar, imajinasi, dan visualisasi terhadap materi dan kondisi yang sebenarnya, sehingga implementasi materi pada kehidupan sehari-hari menjadi lebih optimal.

Dengan kondisi yang seperti tersebut di atas, tampaknya perlu dilakukan suatu kegiatan yang mampu meningkatkan pemahaman dan keterampilan para guru dalam mengembangkan profesionalisme, khususnya dalam pendesainan/ pengembangan media pembelajaran.Hal ini dilakukan melalui kegiatan pengabdian pada masyarakat sebagai salah satu implementasi dari kegiatan Tri Dharma Perguruan Tinggi. Kegiatan pengabdian ini dilakukan untuk Guru SMPN 2 Kediri. Kegiatan ini berupa pelatihan dengan menekankan pada penguasaan terhadap teori dan praktek desain media pembelajaran.

Peran guru di dalam setiap kegiatan pembelajaran persekolahan masih sangat penting. Guru bertanggungjawab atas suksesnya setiap kegiatan pembelajaran yang telah dirancangnya. Guru yang tidak optimal di dalam mempersiapkan desain pembelajaran akan menghasilkan kegiatan pembelajaran yang tidak optimal. Hal itu menyebabkan capaian pembelajaran yang telah ditargetkan tidak tercapai.Dengan demikian, pengembangan kompetensi guru khususnya dalam bidang keterampilan dalam pembuatan media pembelajaran sangat penting untuk dilakukan.

Selain itu, guru masih dihadapkan pada permasalahan yang klasik, yaitu dana yang dibutuhkan untuk membuat/ merancang media pembelajaran. Umumnya, guru menggunakan dana pribadi untuk memenuhi kebutuhan media pembelajaran yang dibutuhkan. Hal inilah yang menjadi salah satu penghambat terciptanya media-media pembejaran yang kreatif dari para guru. Meskipun demikian, ketidakadaan dana bukan merupakan penghalang apabila guru dapat memanfaatkan bahan-bahan sekitar yang murah, seperti bahan dari barang bekas. Dengan mengoptimalkan bahan-bahan yang sudah tidak terpakai, biaya pembuatan media pembelajaran dapat ditekan, sehingga media pembelajaran dapat dihasilkan dan dimanfaatkan dalam kegiatan pembelajaran. Berdasarkan penjelasan pada analisis situasi mitra, dapat diidentifikasikan masalah antara lain

Guru tidak terbiasa merancang media pembelajaran, Guru mengalami kesulitan di dalam mendesain media pembelajaran yang interaktif dengan memanfaatkan bahan-bahan sederhana, Guru merasa terbenani untuk selalu membuat/ menggunakan media jika dana pembuatan media harus dibebankan pada guru, di sisi lain, pihak sekolah tidak memiliki alokasi dana untuk pembuatan media di setiap kegiatan pembelajaran guru, Guru tidak memdapat pendampingan di dalam mengupgrade kemampuan dalam mendesain media pembelajaran yang atraktif, efektif, dan efisien.

Justifikasi permasalahan dijelaskan antara lain Bagaimana membiasakan guru untuk merancang media pembelajaran Bagaimana mengatasi kesulitan guru di dalam mendesain media pembelajaran yang interaktif dengan memanfaatkan bahan-bahan sederhana, Bagaimana solusi yang dapat diberikan untuk dapat membuat media pembelajaran yang atraktif, efektif, dan efisien, Bagaimana membentuk jaringan mitra dalam memberikan pendampingan secara berkesinambungan kepada guru, sehingga tercipta hubungan sinergis yang saling menyokong dan memberi manfaat.

Fenomena ini tak dapat dipungkiri menjadi perhatian buat seluruh pihak, bukan hanya kalangan akademisi Indonesia, tetapi seluruh elemen masyarakat yang menyadari bahwa perkembangan teknologi dan informasi juga mempengaruhi perkembangan akses global yang berkaitan penuh dengan penguasaan bahasa (budaya). Kaitannya dengan hal ini, penulis meyakini bahwa materi 
pelajaran dalam bentuk apapun tidak akan menjadi beban ketika materi tersebut sesuai dengan kapasitas dan kapabilitas anak didik. Proses belajar yang mneyenangkan, ringan, penuh permainan sesungguhnya bisa didesain dalam rangka memaksimalkan keberhasilan pembelajaran. Namun, hal ini memang tidak mudah ketika guru tidak memiliki motivasi dan pengalaman dalam mengelola kelas, khususnya kelas bahasa Inggris untuk siswa SMP.

Oleh karena itu, sebagai bagian dari kepedulian dan partisipasi penulis dalam berbagi pengetahuan sekaligus mengembangkan strategi pembelajaran siswa SMP, maka penulis mencoba menggagas pelatihan pengajaran Quizizz berbahasa inggris untuk siswa smp pada guru-guru SMPN 2 Kediri dengan harapan kegiatan belajarmengajar disekolah tersebut akan lebih dinamis dan menyenangkan. Mereka bisa belajar sambil bermain tanpa menghilangkan substansi pelajaran yang ingin disampaikan atau yang telah ditetapkan oleh kurikulum sekolah. Hal ini menjadi sangat mungkin mengingat metode pengajaran bahasa Inggris sangat variatif, terutama bentuk permainan.

Oleh karena demikian, pengabdian ini menjadi penting untuk dilakukan dengan harapan guru-guru tersebut mampu membawa anak didik mereka menjadi generasi cerdas yang diharapkan ummat dan bangsa. Karena guru memegang peranan penting dalam turut serta menyiapkan generasi-generasi berkualitas. Maka, untuk mampu menciptakan generasi berkualitas tersebut, pada akhirnya perlu mempersiapkan guru-guru yang berkompeten dan professional dibidang mereka masing-masing. Kompetensi kualitas yang diharapkan hanya dapat diraih jika guruguru tersebut mendapatkan input materi maupun pengalaman secara intens, baik secara formal maupun informal.

\section{METODE}

Pelatihan penggunaan media evaluasi Quizizz bagi guru-guru Bahasa inggris, diikuti sebanyak 2 peserta selama bulan November 2021. Metode yang digunakan dalam Pengabdian Kepada Masyarakat dalam rangka peningkatan kompetensi guru-guru adalah melalui pelatihan. Tahapan pertama yang dilakukan adalah dengan mendata jumlah guru yang berada di SMPN 2 Kediri. Langkah selanjutnya adalah dengan melakukan observasi awal mengenai penggunaan media pembelajaran dan evaluasi online dikelas selama pandemi. Setelah mengetahui media evaluasi yang digunakan maka diberikan pelatihan. Pelatihan dilakukan dengan pemberian materi, diskusi/ tanya jawab dan praktek langsung pembuatan soal ujian atau evaluasi dengan menggunakan Quizizz. Dalam pelatihan yang dilaksanakan tim pengabdi, peserta, dan mitra sekolah selalu bersifat kooperatif dalam penyediaan ruang untuk pelatihan dan fasilitas wifi sekolah. Setelah selesai semua pelatihan tim yang bergabung dalam PKM tetap melakukan koordinasi dengan Tim mitra sekolah untuk selalu melakukan pemantauan pemahaman dan penguasaan peserta dalam penggunaan Quizizz . Di akhir kegiatan PKM dilaksanakan evaluasi terhadap kegiatan yang dilakukan. Pelaksanan evaluasi menggunakan angket respon terhadap pelaksanaan PKM. Angket ini diisi oleh guru-guru peserta pelatihan.

Angket respon ini terdiri atas 5 bagian utama yaitu tentang (1) isi pokok materi yang disampaikan oleh tim pengabdi, (2) penyampaian materi tim pengabdi, (3) tanya jawab atau diskusi tim pengabdi dengan peserta pelatihan, dan (4) praktik/pelatihan individu dalam pembuatan media evaluasi online dengan Quizizz dan (5) Hasil pelatihan berupa soal dalam website Quizizz. Setiap pertanyaan terdapat 5 pilihan jawaban yang harus dipilih oleh peserta pelatihan, diantaranya: jawaban sangat setuju, setuju, netral, tidak setuju, sangat tidak setuju. Berdasarkan hasil evaluasi tersebut, para peserta diberikan berbagai penguatan untuk meningkatkan pemahaman secara lebih lanjut tentang efektivitas pemanfaatan media Quizizz dalam melangsungkan kegiatan evaluasi belajar mengajar secara online. Program pengabdian ini akan dikatakan berhasil apabila respon sangat setuju peserta pelatihan terhadap kegiatan ini lebih besar dari $70 \%$, dan tingkat kepuasan serta peningkatan kompetensi guru lebih besar dari $70 \%$.

\section{HASIL DAN PEMBAHASAN}

Selama pelaksanaan kegiatan, mitra yang dalam hal ini adalah Guru Bahasa Inggris SMPN 2 Kediri memberikan konstribusi dengan mengatakan bahwa kegiatan pengabdian pada masyarakat seperti ini sangat mereka perlukan dan sangat bermanfaat dan sekiranya memungkinkan, mereka meminta agar pelatihan mengenai perkembangan tehnologi dapat diberikan kepada guru mata pelajaran lainnya karena guru lain dapat mengadaptasi juga sistem Quizizz . Selain itu, para guru Bahasa Inggris SMPN 2 Kediri juga antusias dalam mengikuti kegiatan pembimbingan menggunakan Quizizz dalam pekan ke-empat sampai pekan keenam dikarenakan mereka merasakan banyak manfaat dari kegiatan ini. 
Dari hasil evaluasi terhadap penggunaan aplikasi Quizizz sebagai media pembelajaran untuk membuat kegiatan belajar mengajar lebih efektif dan variatif, yang peserta lakukan di akhir kegiatan terlihat bahwa para guru Bahasa Inggris sudah mulai paham dengan menggunakan aplikasi quizizz sehingga bisa meningkatkan kemampuan guru dalam penggunaan Media Quizizz dan dapat merekayasa pembelajaran online dengan media pembelajaran yang kreatif dan inovatif yaitu Quizizz.

\section{Potret Permasalahan Lain yang Terekam}

Beberapa potret permasalahan lain yang terekam dalam kegiatan pengabdian pada masyarakat ini selama membimbing Guru Bahasa Inggris dalam penggunaan media Quizizz dalam pelaksanaannya, sebagai berikut:

a. Selama ini guru terbiasa melaksanakan pengajaran menggunakan cara tatap muka sehingga guru-guru tidak memiliki keterampilan yang memadai dalam penggunaan IT terutama pengajaran dengan menggunakan media Aplikasi salah satunya yaitu Quizizz . Hal ini difahami karena ketidakbiasaan dan ketidaktahuan mereka akan media pengajaran online.

b. Mayoritas guru tidak pernah menerima pelatihan pengajaran online seperti penggunaan aplikasi seperti Quizizz, google classroom dan sejenisnya.

c. Kurangnya sarana dan prasarana yang dimiliki sekolah sehingga tidak mampu memfasilitasi guru dalam proses pembelajaran Bahasa inggris baik itu untuk guru terutama dalam media ataupun metode pengajaran online dan juga untuk siswanya.

d. Kurangnya kesempatan yang dimiliki oleh guru dalam mengembangkan keterampilan dan kreatifitas mereka dalam mengajar secara online sehingga diharapkan dengan pengabdian yang dilakukan ini akan memberikan pencerahan bagi kedua belah pihak untuk saling mengoreksi dan memikirkan kebaikan para guru- guru Bahasa inggris kedepannya sekaligus menjadi solusi pemecahan masalah pengajaran bahasa inggris bagi siswa siswi SMPN 2 Kediri.

\section{Hasil Capaian dan Luaran}

Dalam faktanya pada tahun 2020 hingga saat ini fenomena Covid-19 memberikan tantangan tersendiri untuk dunia pendidikan bahkan di seluruh dunia yang menuntut harus siap melakukan pembelajaran belajar mengajar secara online/online hingga menjadikan syarat perkuliahan dengan kompetensi, tepat, cermat dan cepat. Di sisi lain kompetensi, sistem, dan teknis belum mendukung sepenuhnya untuk itu. Dikarenakan selama ini pembelajaran dilaksanakan oleh tenaga pendidik terbiasa dengan pola lama dengan teacher centered, pembelajaran online baru sampai pada wacana sebagai perangkat teknis, belum mengarah pada media pengubah cara berpikir dan bertindak, sebagai paradingma pembelajaran berbasis student center, untuk menjadikan siswa kreatif, inovatif yang menghasilkan karya, wawasan pembentukan siswa menjadi pembelajar sepanjang hayat.

Pembelajaran online memiliki beberapa dampak terhadap siswa yaitu pembelajaran online masih membingungkan siswa, siswa menjadi pasif, kurang kreatif dan kurang produktif, penumpukan informasi/ konsep pada siswa kurang bermanfaat, siswa mengalami stress, serta peningkatan kemampuan literasi bahasa siswa. Hal ini dapat menjadi evaluasi agar pembelajaran online dapat diupayakan diterima dengan baik oleh siswa tanpa mengurangi esensi pendidikan itu sendiri.

Berdasarkan hasil pembahasan di atas, dapat diketahui bahwa terdapat dua jenis pembelajaran yang dilaksanakan di Kota Mataram pada masa pandemi Covid-19. Pertama adalah dengan pembelajaran online. Tenaga pendidik memberikan pembelajaran secara online melalui google classroom atau zoom meeting dengan mengirim teks, video, rekaman suara, power point, dan tugas- tugas kepada siswa. Kedua pembelajaran offline yakni pembelajaran yang dilaksanakan tanpa melalui jaringan atau di luar jaringan. Pembelajaran tersebut bisa berupa pembelajaran dengan penugasan, dan pembelajaran secara berkelompok.

Hambatan yang dihadapi oleh guru, siswa, dan orang tua siswa adalah minimnya perangkat pembelajaran online, SDM yang kurang mumpuni, dan sikap negatif baik itu dari guru, siswa, dan orang tua. Pembelajaran online dan offline yang dilaksanakan dengan tanpa tatap muka memerlukan sikap positif guru, siswa, dan orang tua siswa. Ketiga elemen tersebut menjadi pokok keberhasilan pembelajaran di masa pandemi Covid-19. Berdasarkan hal di atas, maka tim pelaksana pengabdian pada masyarakat akhirnya menawarkan penggunaan media pembelajaran elektronik yaitu Quizizz application atau aplikasi Quizizz pada guru guru Bahasa inggris di SMPN 2 Kediri.

Quizizz merupakan sebuah web tool untuk membuat permainan kuis interaktif yang digunakan dalam pembelajaran di kelas. Kuis 
interaktif yang dibuat memiliki hingga 4 pilihan jawaban termasuk jawaban yang benar dan dapat ditambahkan gambar ke latar belakang pertanyaan.

Quizizz dapat memberikan data dan statistik tentang hasil kinerja siswa secara langsung. Quizizz tidak hanya dapat dikerjakan saat pembelajaran di kelas saja, tetapi juga dapat dibuat soal untuk pekerjaan rumah (PR), sehingga dapat dimainkan kapan saja dan dimana saja oleh siswa asalkan tidak melebihi batas waktu yang sudah ditentukan.

Dengan Quizizz ini, siswa akan merasa ditantang, karena ada skor yang diperoleh dengan menjawab secara cepat dan tepat, kecepatan akan ada skor sendiri. Selain itu akan ada persaingan, karena Quizizz langsung membuat ranking yang bersifat live antar peserta Quizizz .

Menyenangkan karena akan ada suasana musik untuk menyemangati, dan juga meme yang lucu serta menyemangati.

Kelebihan dari Quizizz bagi siswa adalah siswa tidak dapat mencontek sesama temannya, karena soal yang diberikan kepada siswa satu dengan yang lainnya telah diacak. Soal bisa dibuat dengan ketentuan waktu tertentu yang membuat siswa tidak punya kesempatan untuk bertanya dengan orang sekitar atau melihat buku catatan miliknya.

Setelah mengerjakan kuis, siswa dapat mengetahui rangking yang dia dapat dari keseluruhan siswa yang mengerjakan soal tersebut. tidak hanya itu, siswa juga mengetahui soal dan jawaban yang betul dari soal yang telah dikerjakannya.

Keuntungan Quizizz bagi guru adalah akan ada grading otomatis, kemudian quiziz membuat analisis butir soal, yang semuanya dapat diunduh berupa file excel. Laporan cukup detail, setiap siswa akan dilaporkan jawaban benar-salahnya, serta prosentase pencapaian quiz untuk seluruh siswa. Selain itu sebenarnya, hasil quiz setiap siswa dapat diemail ke orang tua siswa.

Pengguna Quizizz dalam hal ini siswa dapat belajar bahasa Inggris dengan mudah, santai dan menyenangkan yang dilengkapi dengan Quiz, exercises yang sesuai dengan topic yang bisa dipilih oleh guru Bahasa inggris. Pembelajaran dengan menggunakan Quizizz memudakan guru Bahasa inggris dalam mengajar dan merakit materi yang akan guru ajarkan kepada siswa siswinya. Selain itu cara aplikasi ini memberikan kebebasan kepada guru dalam berkreasi membuat materi untuk siswa baik berupa gambar, suara, maupun video. Aplikasi ini juga di lengkapi dengan beberapa fitur lain yang lebih menyenangkan untuk anak seperti games
Bahasa inggris dan juga beberapa gambar yang menarik dan lainnya dengan menampilkan bahasa inggris yang sering dipergunakan sehingga siswa dapat belajar dengan menggunakan aplikasi ini dengan lebih mudah

\section{SIMPULAN DAN SARAN}

Aplikasi Quizizz atau Quizizz application yang dapat digunakan pada IOS, Android, dan Windows Phone ini dibuat sedemikian rupa agar pengguna bisa terus membuat materi ataupun quiz atau test baik untuk siswa maupun guru dan meningkatkan kemampuan dalam berbagai mata pelajaran salah satunya yakni bahasa inggris kapan pun dan dimanapun.

Pembelajaran dalam Quizizz ini dirancang seperti ruang untuk membuat atau merancang materi ajar bagi siswa, latihan latihan yang di rancang oleh guru itu sendiri atau bisa diperoleh langsung dari laman yang telah disediakan oleh Quiziz, games seru dan menyenang bagi siswa menarik dan mudah diserap dan sangat ampuh untuk membuat banyak orang mempelajari pengetahuan baru maka penggunaan Quizizz application atau aplikasi Quizizz membuat pembelajaran menjadi lebih mudah di rancang dan dikerjakan oleh siswa dan menyenangkan untuk digunakan khususnya bahasa inggris yang dipilih untuk dipelajari dalam kegiat pengabdian pada masyarakat ini.

Meskipun Quizizz dibuat untuk belajar berbagai mata pelajaran lainnya, namun dapat dilaksanakan sambil bersantai, sehingga siswaSMPN 2 Kediri dapat menambah pengetahuan bahasa inggrisnya dengan lebih menyenangkan karena penggunaan media yang efektif dan menarik.

Dalam hal ini penulis menyarankan agar tenaga pengajar dapat memanfaatkan aplikasi pembelajaran bahasa yang menarik, mampu belajar kosakata melalui gambar, belajar kalimat sehari-hari, dan mengucapkan kosakata pada bahasa yang ingin dipelajari melalui aplikasi yang berbasis mobile atau web. Siswa dapat memilih beberapa media pembelajaran lainnya sebagai alternatif untuk meningkatkan kemampuan atau kompetensi berbahasa asing siswa.

\section{UCAPAN TERIMAKASIH}

Pengabdian Kepada Masyarakat ini didanai oleh Lembaga Penelitian dan Pengabdian kepada Masyarakat Universitas Muhammadiyah Mataram. Kami berterima kasih kepada kepala SMPN 2 Kediri, serta guru-guru mata pelajaran yang telah berpartisipasi aktif demi suksesnya PKM ini. 


\section{DAFTAR RUJUKAN}

Agung, S,.Sri, W dan Dwi, S, (2019). "Implementasi media game edukasi Quizizz untuk meningkatkan hasil belajar matematika materi sistem persamaan linear tiga variabel kelas $X$ IPA 7 SMA Negeri 15 Semarang TA 2019/2020". Seminar Nasional Edusainstek.

Andi Achru P, (2019). Pengembangan Minat Belajar Dalam Pembelajaran. Jurnal Idaarah, Vol.III, No.2

Anshori, S. (2017). "Pemanfaatan Teknologi Informasi dan Komunikasi sebagai Media Pembelajaran". Civil Culture : Jurnal IImu Pendidikan PKn dan Sosial Budaya, 88-100.

Benny A.P, (2017). Media \& Teknologi dalam Pembelajaran Jakarta: Prenada Media.

Cahyani, A C \& Brillian R, (2020). "Keefektifan Penggunaan Media Pembelajaran Berbasis Game Edukasi Quizizz Terhadap Hasil Belajar Teknologi Perkantoran Siswa Kelas X SMK Ketintang Surabaya". Jurnal Pendidikan Administrasi Perkantoran (JPAP), No. 2, Vol. 8

Destyan D., Arlin, A dan Viarti E. (2020). Pengaruh Game Edukasi Quizizz Terhadap Keaktifan dan Hasil Belajar Matematika Siswa. Seminar Nasional Penelitian LPPM UMJ

Fathul M dan Nailur R. (2012). Permainan Edukatif Pendukung Pembelajaran Bahasa Arab (2). Yogyakarta: DIVA Press,

Fitrianingsih, Darsono, Adelina Hasyim, (2014). "Peningkatan Minat Dan Hasil Belajar Siswa Memanfaatkan Media Audio Visual Mata Pelajaran Pkn". Jurnal Studi Sosial. No.1, Vol.2

Hermawan A, (2014). Metodologi Pembelajaran Bahasa Arab. Bandung: Rosda.

http://pendis.kemenag.go.id/index.php?a=detil berita\&id=6595

https://lpmpbengkulu.kemdikbud.go.id/

https://wirahadie.com/cara-membuat-soalonline/

https://www.dosenpendidikan.co.id/hasilbelajar/

Jamil Suprihatiningrum. (2016). GURU PROFESIONAL Pedoman Kinerja, Kualifikasi \& Kompetensi Guru, Yogyakarta: AR-RUZZ MEDIA.

Luh Devi H., Nurhasanah., Maria E.S dan Heru K, .(2020). "Pembelajaran pada masa pandemi covid-19". Jurnal Teknologi Pendidikan
Volume 5, Nomor 1, Desember 2021.

p-ISSN : 2614-5251

e-ISSN : 2614-526X

Mahmud, (2011). Metode Penelitian Pendidikan.(Bandung: Pustaka Setia.

Muna Wa, (2011). Metodologi Pembelajaran Bahasa Arab, Yogyakarta : Teras

Noor M, (2010). Media Pembelajaran Berbasis Teknologi Jakarta: PT. Multi Kreasi.

Nugrahani F. (2014). Metode Penelitian Kualitatif dalam Penelitian Pendidikan Bahasa. Surakarta.

Rosyidi A,W. (2009). Media Pembelajaran Bahasa Arab. Malang : UIN Malang Press

Salsabila,U H,.Habiba,I S,.Amanah,I L,.Istiqomah,N A,.Difany S, (2020). "Pemanfaatan Aplikasi Quizizz Sebagai Media Pembelajaran Ditengah Pandemi Pada Siswa SMA". Jurnal IImiah IImu Terapan Universitas Jambi. No. 2, Vol.4.

Sinar. (2018). Metode Active Learning Upaya Peningkatan Keaktifan Dan Hasil Belajar Siswa. Yogyakarta: Deepublish

Sugiyono, (2016). Metode Penelitian Kuantitatif, Kualitatif dan R\&D. Bandung: Alfabeta.

Syaiful Bahri D. (2008). Psikologi Belajar Edisi 2. Jakarta : PT Rineka Cipta

Wandah Wibawanto. (2020). Game Edukasi RPG(Role Playing Game).(Semarang: LPPM UNNES.

Yaumi M, (2018). Media dan Teknologi Pembelajaran Jakarta: Kencana 